\title{
ARE CROP COEFFICIENTS FOR SDI DIFFERENT FROM THOSE FOR SPRINKLER IRRIGATION APPLICATION?
}

\author{
S. R. Evett，G. W. Marek，P. D. Colaizzi，D. Brauer，T. A. Howell
}

Beyond 2020,

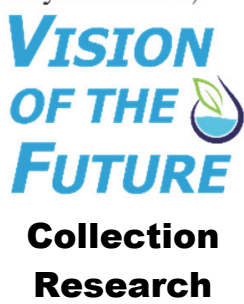

\section{HighLIGHTS}

- Crop coefficients for SDI scheduling for grain corn should be reduced by $\sim 10 \%$ from those used for sprinkler irrigation.

- FAO 56 methods to calculate crop coefficients for surface drip irrigation under full-cover plastic mulch were applicable to SDI.

- A recent drought-resistant corn hybrid appeared to begin rapid leaf area development about 10 days earlier than older hybrids.

- A recent drought-resistant corn hybrid appeared to finish earlier than older hybrids by about 15 days.

ABSTRACT. Subsurface drip irrigation (SDI) has become an important irrigation application method in the U.S. Southern High Plains where pan evaporation exceeds 2,400 mm per year. Early research comparing SDI with spray sprinklers showed that SDI was over-applied when scheduling irrigations using crop coefficients developed using sprinkler irrigation. Thus, crop coefficients developed using SDI may be smaller than those developed using sprinkler irrigation. Grain corn was grown for two years on large, precision weighing lysimeters at Bushland, Texas, with two lysimeters irrigated by SDI and two by mid-elevation spray (MESA) irrigation. Data used in this study were for fields irrigated to replenish soil water in the top $1.5 \mathrm{~m}$ of the soil to field capacity, as indicated by weekly neutron probe readings (100\% replenishment). Crop coefficients developed for SDI $\left(K_{C_{-} S D I}\right)$ were compared with those developed for MESA ( $\left.K_{c_{-} M E S A}\right)$ using ASCE standardized reference ET equations. The value of $K_{c \_S D I}$ ranged from 0.83 to 0.89 of $K_{c_{\perp} M E S A}$ for the two years. Values of $K_{c_{\perp} S D I}$ remained consistently less than $K_{c-M E S A}$ even after maximum leaf area index was reached, indicating that considerable evaporative loss from the soil surface occurred with MESA irrigation even after full canopy cover. When we shortened the initial period after planting from 30 to $20 \mathrm{~d}$ and followed $F A O 56$ recommendations for surface drip irrigation under full-cover plastic mulch, we calculated basal $K_{c}\left(K_{c b}\right)$ values (ET $T_{o}$ basis) that were reasonably close to our $K_{c}$ values for SDI for the crop development and early mid-season periods but were greater than our data for the later mid-season and late season periods.

Keywords. Crop coefficient, FAO56, MESA, SDI, Sprinkler irrigation, Subsurface drip irrigation.

$\mathrm{T}$ he use of microirrigation expanded to $10 \%$ of U.S. irrigated lands by 2018 (USDA-NASS, 2019). Subsurface drip irrigation (SDI) is a microirrigation method that has seen increased use for row crops, particularly in the Texas High Plains where it now is

\footnotetext{
cC)(1) $\ominus$ The authors have paid for open access for this article. This work is licensed under a Creative Commons AttributionNonCommercial-NoDerivatives 4.0 International License https://creative commons.org/licenses/by-nc-nd/4.0/

Submitted for review in January 2019 as manuscript number NRES 13920; approved for publication as a Research Article and as part of the National Irrigation Symposium 2020 Collection by the Natural Resources \& Environmental Systems Community of ASABE in March 2020.

Mention of company or trade names is for description only and does not imply endorsement by the USDA. The USDA is an equal opportunity provider and employer.

The authors are Steven R. Evett, Research Soil Scientist, Gary W. Marek, Research Agricultural Engineer, Paul D. Colaizzi, Research Agricultural Engineer, David Brauer, Research Leader, and Terry A. Howell, Research Leader (retired), USDA-ARS Soil and Water Management Research Unit, Bushland, Texas. Corresponding author: Steven R. Evett, USDA-ARS SWMRU, 300 Simmons Rd., Unit 10, Bushland, TX 79012; phone: 806-356-5775; e-mail: steve.evett@usda.gov.
}

used on $6.6 \%$ of the irrigated area (USDA-NASS, 2019). The 175,000 ha of SDI in the Southern High Plains of the Texas Panhandle (HPWD, 2016) are predominantly used for cotton, but also corn. Deficit irrigation has been shown to be more successful with SDI than with mid-elevation spray application (MESA) for sorghum, soybean, and cotton (Colaizzi et al., 2004, 2006a, 2009). For cotton, the relatively larger lint yield and fiber quality with SDI were tied to warmer soil temperatures with SDI compared with soil that was cooled by evaporation after MESA irrigation (Colaizzi et al., 2006b). Crop coefficients for irrigation scheduling in the Southern High Plains of Texas were developed using sprinkler irrigation, mainly MESA, by the USDA-ARS at Bushland, Texas, for alfalfa, corn, cotton, sorghum, soybean, sunflower, and winter wheat (Evett et al., 2016). However, experiments comparing SDI, low-elevation precision application (LEPA), low-elevation spray application (LESA), and MESA showed that scheduling irrigations using crop coefficients developed using sprinkler irrigation resulted in over-irrigation with SDI, deep percolation losses of water and nutrients, and yield reduction of sorghum due to these factors and an overly wet profile (Colaizzi et al., 2009). 
Crop coefficients are used to estimate crop evapotranspiration $\left(\mathrm{ET}_{c}\right)$ using the equation:

$$
\mathrm{ET}_{c}=K_{c} \mathrm{ET}_{r e f}=\left(K_{s} K_{c b}+K_{e}\right) \mathrm{ET}_{r e f}
$$

where

$K_{c}=$ crop coefficient that varies with crop and growth stage and may vary with region and with irrigation application method.

$\mathrm{ET}_{r e f}=$ reference ET calculated from weather data using a given method.

$K_{s}=$ soil water deficit coefficient ( 0 to 1$)$ describing the effect of soil water deficit on ET.

$K_{c b}=$ basal coefficient defined for a non-water-deficit situation with a dry soil surface, which may vary with crop, growth stage, region, and irrigation application method.

$K_{e}=$ coefficient accounting for evaporation from soil and crop surfaces resulting from irrigation and precipitation.

Values of $K_{c b}$ may be determined by inverting equation 1 for days when there is no soil water deficit and the soil surface is dry, in which case $K_{s}=1, K_{e}=0$, and thus $K_{c b}=$ $\mathrm{ET}_{c} / \mathrm{ET}_{\text {ref. }}$. Methods for determining $K_{c b}, K_{s}$, and $K_{e}$ based on weather at a particular location are discussed in Annex 8 of FAO Irrigation and Drainage Paper No. 56 (Allen et al., 1998; referred to herein as FAO 56), Tolk and Howell (2001), and Howell et al. (2004). Methods for calculating reference ET for a short crop (grass, $\mathrm{ET}_{o}$ ) and a tall crop (alfalfa, $\mathrm{ET}_{r}$ ) are given by ASCE (2005).

Because crop coefficients may be affected by irrigation application method, the USDA-ARS Conservation and Production Research Laboratory at Bushland, Texas, initiated weighing lysimeter based comparisons of SDI and MESA in the 2013 growing season. Two seasons of corn showed that evaporative losses from MESA irrigated crops were significantly and importantly greater than observed with SDI, while yields and crop water productivities were typically equal or greater with SDI (Evett et al., 2019). The data from these two seasons are used herein to calculate crop coefficients for SDI and MESA irrigated corn and to answer two questions: "Are crop coefficients for SDI different from those for sprinkler irrigation?" and "If so, then by how much and when during the growing season?"

\section{Methods AND MATERiAls}

Corn (Zea mays L) was grown for grain in 2013 and 2016 at the USDA-ARS Conservation and Production Research Laboratory, Bushland, Texas $\left(35^{\circ} 11^{\prime} \mathrm{N}, 102^{\circ} 6^{\prime} \mathrm{W}, 1170 \mathrm{~m}\right.$ above MSL) on a gently sloping $(<0.3 \%)$ Pullman soil (fine, mixed, superactive, thermic Torrertic Paleustoll). Four 4.4 ha fields, approximately square in shape and adjacent to each other, each contained a large weighing lysimeter in the center. The precision lysimeters were nominally $3 \mathrm{~m} \times 3 \mathrm{~m}$ in surface area, $2.3 \mathrm{~m}$ deep, contained undisturbed cores of the Pullman soil obtained on site, and had an accuracy of $0.04 \mathrm{~mm}$ water depth equivalent or better (Evett et al., 2012; Marek et al., 1988). The fields and the lysimeters they contained were designated NE, SE, NW, and SW according to the cardinal directions. The NE and SE lysimeters and fields were irrigated by SDI, and the NW and SW lysimeters and fields were irrigated by MESA using a ten-span linear-move system as described by Evett et al. (2019). Adaptation of SDI for the NE and SE weighing lysimeters was described by Evett et al. (2018a). Corn was a 109-day drought-tolerant variety (Pioneer variety 1151AM AquaMax, $\leq 80 \% \mathrm{Bt}$ ) and was planted on 16-17 May 2013 under MESA irrigation, on 22-23 May 2013 in the SDI fields and on 10-11 May 2016 in all fields. These are typical dates for corn planting in the region (tables 1 and 2). Corn harvest was on 15 October 2013 and on 13 and 17 October 2016. Crops were managed and fertilized for high yield, as detailed by Evett et al. (2019).

Soil water content was measured at center depths of 0.10 to $2.30 \mathrm{~m}$ in $0.20 \mathrm{~m}$ increments in each of eight access tubes in the field around each lysimeter and in two access tubes in each lysimeter (to $1.90 \mathrm{~m}$ depth) on a weekly basis, unless prevented by wet field conditions, using a field-calibrated neutron probe and depth-control stand (Evett et al., 2008). Once the crop was established, irrigations were scheduled weekly to replenish water content in the top $1.5 \mathrm{~m}$ of the soil profile to field capacity (i.e., replenishing $100 \%$ of crop ET, designated SDI $100 \%$ and MESA $100 \%$ ), with the exception of one MESA field where irrigations were $75 \%$ of full crop ET after crop establishment (designated MESA 75\%) (tables 3 and 4). As explained by Evett et al. (2019), the MESA $75 \%$ deficit irrigation treatment was established to complete a previous longer-term deficit irrigation study. In some cases, two or even three irrigations were required in a week to replenish water used by the crop. Irrigations by sprinkler and by SDI typically did not occur on the same day. Neutron probe readings were delayed until the soil surface was dry enough to walk on and then immediately followed by irrigation when called for, which means that the data in figure 2 represent the driest, not the most common, conditions that the crop experienced. Irrigation and precipitation depths for different parts of the season are given in table 3 and figure $1 \mathrm{a}$ for 2013 and in table 4 and figure $1 \mathrm{~b}$ for 2016, as reported by Evett et al. (2019). The soil profile in early 2013 was quite dry, and preplant irrigation and irrigation immediately after planting were required to plant and germinate the crop. This resulted in a full soil profile in the SDI fields by the time neutron probe sensing began, while crop germination with MESA irrigation was accomplished with less frequent irrigations that did not penetrate to the $1.5 \mathrm{~m}$ depth (figs. $2 \mathrm{~b}$ and $2 d$ ). Irrigations in the SDI and MESA 100\% fields maintained soil water storage to more than the management-allowed depletion level throughout the season. In 2016, the soil profile was much wetter following a wet winter, and no preplant irrigation and not much irrigation immediately after planting were needed. Again, irrigations in the SDI and MESA $100 \%$ fields kept soil water storage to more than the management-allowed depletion level (figs. 2a and 2c).

Evapotranspiration (ET) was determined on a $5 \mathrm{~min}, 15 \mathrm{~min}$, and daily basis using data analysis and quality control procedures described by Marek et al. (2014) and Evett et al. (2019). Reference ET for short $\left(\mathrm{ET}_{o}\right)$ and tall $\left(\mathrm{ET}_{r}\right)$ crops was calculated on a $15 \mathrm{~min}$ and daily basis using procedures from ASCE (2005), as promulgated by Allen (2012), and 15 min weather data from the research weather station of the USDA-ARS Soil and Water Management Research Unit 
(SWMRU) at Bushland, Texas, which is immediately east of the lysimeter fields. The weather station instrumentation and data quality assurance and control procedures were described by Evett et al. (2018b). Simple crop coefficients $\left(K_{c}\right)$ were calculated as the ratio of daily measured ET and tall crop reference ET $\left(\mathrm{ET}_{r}\right)$. Crop coefficients were also calculated using procedures described in FAO 56 and further described by Tolk and Howell (2001) and Howell et al. (2015).

Table 1. Corn crop management in 2013.

\begin{tabular}{|c|c|c|}
\hline $\begin{array}{c}\text { Date } \\
(2013)\end{array}$ & $\begin{array}{c}\text { Day } \\
\text { of Year }\end{array}$ & Action \\
\hline \multicolumn{3}{|c|}{ NW and SW fields (MESA) } \\
\hline 23-24 Apr. & $113-114$ & Applied 32-0-0 fertilizer at a rate of $236 \mathrm{~kg} \mathrm{~N} \mathrm{ha}^{-1}$ and incorporated using disc plow. \\
\hline 2 May & 122 & Built beds using disk bedder. \\
\hline 16-17 May & $136-137$ & $\begin{array}{l}\text { Planted Pioneer corn variety } 1151 \mathrm{HR} \text { Aqua Max with } \mathrm{Bt} \text { at a rate of } 81,500 \text { seeds }^{-1} \mathrm{~h}^{-1} \text { using row planter. Hand-planted } \\
\text { lysimeters at a slightly greater rate. Measured plant stand was greater than the seeding rate set in the planter (stand } \\
\text { was } 96,600 \mathrm{ha}^{-1} \text { ). Overseeding during hand-planting of the lysimeters allowed thinning to match the field plant stand. }\end{array}$ \\
\hline 24 May & 144 & Corn fully emerged. Thinned lysimeter areas to match field plant density. \\
\hline 28 May & 148 & Hail resulted in approximately $13 \%$ stand loss, more on east fields than on west fields. \\
\hline 7 June & 158 & $\begin{array}{l}\text { Started treatment irrigations using Nelson \#20 nozzles on the NW field to target applications at } 75 \% \text { of full (100\%) } \\
\text { irrigation applied to the SW field using \#23 nozzles. }\end{array}$ \\
\hline 11 June & 162 & $\begin{array}{l}\text { Sprayed west fields with Roundup Power Max (glyphosate) and GMAX Lite (atrazine and S-metolachlor), mixed at } \\
\text { active ingredient rates of } 771 \text { and } 631 \mathrm{~g} \mathrm{ha}^{-1} \text {, respectively. }\end{array}$ \\
\hline 12 June & 163 & Furrow diked west fields. \\
\hline 30 July & 211 & Applied $27 \mathrm{~kg} \mathrm{~N} \mathrm{ka}^{-1}$ as liquid 32-0-0 fertilizer using Nelson \#22 nozzles for uniform irrigation. \\
\hline 31 July & 212 & Applied $29 \mathrm{~kg} \mathrm{~N} \mathrm{ha}^{-1}$ as liquid 32-0-0 fertilizer using Nelson \#22 nozzles for uniform irrigation. \\
\hline 25 June & 254 & Staged plants and harvested for biomass and LAI six times, ending on 11 September. \\
\hline 15 Oct. & 288 & Hand-harvested lysimeters and random replicated field locations. \\
\hline 21 Oct. & 294 & Combine-harvested field in ten approximately equal-sized sections (measured areas). \\
\hline \multicolumn{3}{|c|}{ NE and SE fields (SDI) } \\
\hline 23-24 Apr. & $113-114$ & Applied $172 \mathrm{~kg} \mathrm{~N} \mathrm{ha}^{-1}$ as liquid 32-0-0 fertilizer on east field and incorporated using disc plow. \\
\hline 22-23 May & $142-143$ & $\begin{array}{l}\text { Planted Pioneer corn variety } 1151 \mathrm{HR} \text { Aqua Max with Bt at a rate of } 81,500 \text { seeds ha }^{-1} \text { using row planter. Hand-planted } \\
\text { lysimeters at a slightly greater rate. Measured plant stand was greater than the seeding rate set in the planter (stand } \\
\text { was } 84,000 \mathrm{ha}^{-1} \text { ). Overseeding during hand-planting of the lysimeters allowed thinning to match the field plant stand. }\end{array}$ \\
\hline 31 May & 151 & Rotary hoed east field to break up crust and allow emergence. \\
\hline 2 June & 153 & Corn fully emerged on lysimeters, spotty in fields. \\
\hline 21 June & 172 & Sprayed Roundup Power Max (glyphosate) at active ingredient rate of $756 \mathrm{~g} \mathrm{ha}^{-1}$. \\
\hline 25 June & 254 & Staged plants and harvested for biomass and LAI six times, ending on 11 September. \\
\hline 15 Oct. & 288 & Hand-harvested lysimeters and random replicated field locations. \\
\hline 23 Oct. & 296 & Combine-harvested field in ten approximately equal-sized sections (measured areas). \\
\hline
\end{tabular}

Table 2. Corn crop management in 2016.

\begin{tabular}{|c|c|c|}
\hline $\begin{array}{l}\text { Date } \\
(2016)\end{array}$ & $\begin{array}{c}\text { Day } \\
\text { of Year }\end{array}$ & Action \\
\hline \multicolumn{3}{|c|}{ NW and SW fields (MESA) } \\
\hline 6 Apr. & 97 & $\begin{array}{l}\text { Fertilized NW field at rates of } 202 \mathrm{~kg} \mathrm{~N} \mathrm{ha}^{-1} \text { and } 84 \mathrm{~kg} \mathrm{P} \mathrm{ha}^{-1} \text { using a combination of 32-0-0 and 10-34-0. Fertilized SW } \\
\text { field at rates of } 135 \mathrm{~kg} \mathrm{~N} \mathrm{ha}^{-1} \text { and } 84 \mathrm{~kg} \mathrm{P} \mathrm{ha}^{-1} \text { using a combination of 32-0-0 and 10-34-0. SW field received less N } \\
\text { because it would be irrigated at the full rate and would receive more in-season fertilizer through the MESA sprinkler. }\end{array}$ \\
\hline 11 Apr. & 102 & Disked west field. \\
\hline 11 May & 132 & $\begin{array}{l}\text { Planted Pioneer variety 1151 AM AquaMax }(\leq 80 \% \mathrm{Bt}) \text { at a rate of } 87,475 \text { seeds ha }{ }^{-1} \text { according to planter settings. Actual } \\
\text { stand count after emergence was approximately } 93,900 \text { plants }^{-1} \mathrm{~h}^{-1} \text {. }\end{array}$ \\
\hline 16 May & 137 & $\begin{array}{l}\text { Sprayed both fields with Charger Max ATZ (S-metolachlor, atrazine) at active ingredient rates of 1,610 and 2,080 } \mathrm{g} \mathrm{ha}^{-1} \text {, } \\
\text { and Roundup Power Max (glyphosate) at active ingredient rate of } 864 \mathrm{~g} \mathrm{ha}^{-1} \text {, respectively. }\end{array}$ \\
\hline 21 May & 142 & Corn emerged. \\
\hline 8 June & 160 & Diked west fields using Bigham Bros diker. \\
\hline 17 June & 169 & Fertigated $39 \mathrm{~kg} \mathrm{~N} \mathrm{ha}^{-1}$ of $32-0-0$ \\
\hline 1 July & 183 & Fertigated $40 \mathrm{~kg} \mathrm{~N} \mathrm{ha}^{-1}$ of 32-0-0. Deficit irrigation treatment (75\%) began on SW field using smaller nozzles. \\
\hline 12 July & 194 & Fertigated $40 \mathrm{~kg} \mathrm{~N} \mathrm{ha}^{-1}$ of $32-0-0$ \\
\hline 17 Oct. & 291 & Started combine harvest. \\
\hline \multicolumn{3}{|c|}{ NE and SE fields (SDI) } \\
\hline 5 Apr. & 96 & Fertilized with liquid at a rate of $202 \mathrm{~kg} \mathrm{~N} \mathrm{ha}^{-1}$ and $84 \mathrm{~kg} \mathrm{P} \mathrm{ha}^{-1}$ using a combination of $32-0-0$ and $10-34-0$. \\
\hline 11 Apr. & 102 & Disked east field. \\
\hline 10 May & 131 & $\begin{array}{l}\text { Planted Pioneer variety 1151AM AquaMax }(\leq 0 \% \mathrm{Bt}) \text { at a rate of } 87,475 \text { seeds }^{-1} \mathrm{ha}^{-1} \text { according to planter settings. Actual } \\
\text { stand count after emergence was approximately } 93,900 \text { plants }^{-1} \mathrm{a}^{-1} \text {. }\end{array}$ \\
\hline 16 May & 137 & $\begin{array}{l}\text { Sprayed both fields with Charger Max ATZ (S-metolachlor, atrazine) active ingredient rates of 1,610 and 2,080 } \mathrm{g} \mathrm{ha}^{-1} \text {, } \\
\text { and Roundup Power Max (glyphosate) at active ingredient rate of } 864 \mathrm{~g} \mathrm{ha}^{-1} \text {, respectively. }\end{array}$ \\
\hline 17 May & 138 & Hand-watered lysimeters and area around the outside of the box. \\
\hline 21 May & 142 & Corn emerged. \\
\hline 9 June & 161 & Diked east fields using Bigham Bros diker. \\
\hline 16 June & 168 & Fertigated $38 \mathrm{~kg} \mathrm{~N} \mathrm{ha}^{-1}$ of $32-0-0$ \\
\hline 7 July & 189 & Fertigated $38 \mathrm{~kg} \mathrm{~N} \mathrm{ha}^{-1}$ of $32-0-0$. \\
\hline 14 July & 196 & Fertigated $38 \mathrm{~kg} \mathrm{~N} \mathrm{ha}^{-1}$ of $32-0-0$. \\
\hline 13 Oct. & 287 & Started combine harvest. \\
\hline
\end{tabular}


Table 3. Irrigation, precipitation, evapotranspiration (ET), yield, and crop water productivity for corn in 2013. Yields are combine-harvested and adjusted to zero water content (dry). The NE and SE fields were irrigated with SDI, and the NW and SW fields were irrigated with MESA. The NE, SE, and SW fields were fully irrigated. The NW field was irrigated at $75 \%$ of the SW field beginning on DOY 158 (7 June). ${ }^{\text {[a] }}$

\begin{tabular}{|c|c|c|c|c|}
\hline \multirow[b]{2}{*}{ Corn in 2013} & \multicolumn{4}{|c|}{ Field and Lysimeter (and Irrigation Method) } \\
\hline & $\begin{array}{c}\mathrm{NE} \\
(\mathrm{SDI})\end{array}$ & $\begin{array}{c}\mathrm{SE} \\
(\mathrm{SDI})\end{array}$ & $\begin{array}{c}\text { NW } \\
(\text { MESA 75\%) }\end{array}$ & $\begin{array}{c}\text { SW } \\
(\text { MESA } 100 \%)\end{array}$ \\
\hline Preplant irrigation (60 days before planting) $(\mathrm{mm})$ & 10 & 8 & 112 & 113 \\
\hline Irrigation from planting to initiation of deficit (DOY 157) $(\mathrm{mm})$ & 229 & 231 & 21 & 23 \\
\hline Irrigation after deficit irrigation had begun (DOY 157) (mm) & 293 & 295 & 314 & 448 \\
\hline Total irrigation $(\mathrm{mm})$ & 532 & 533 & 447 & 583 \\
\hline Preplant precipitation (60 days before planting) (mm) & 44 & 29 & 29 & 32 \\
\hline Precipitation from planting to DOY $157(\mathrm{~mm})$ & 38 & 33 & 41 & 45 \\
\hline Precipitation after DOY $157(\mathrm{~mm})$ & 214 & 208 & 203 & 211 \\
\hline Total growing season precipitation $(\mathrm{mm})$ & 251 & 241 & 245 & 256 \\
\hline ET from planting to 25 DAP $(\mathrm{mm})$ & 104 & 108 & 143 & 137 \\
\hline ET from first preplant irrigation to $25 \mathrm{DAP}(\mathrm{mm})$ & 132 & 131 & 231 & 218 \\
\hline Total lysimeter ET $(\mathrm{mm})^{[\mathrm{b}]}$ & 682 & 667 & 708 & 814 \\
\hline Total field ET (neutron probe basis, same date ranges) $(\mathrm{mm})$ & $678 \mathrm{~b}$ & $643 \mathrm{~d}$ & $660 \mathrm{c}$ & $762 \mathrm{a}$ \\
\hline Dry grain yield $\left(\mathrm{Mg} \mathrm{ha}^{-1}\right)$ & $11.38 \mathrm{a}$ & $10.87 \mathrm{~b}$ & $7.24 \mathrm{~d}$ & $9.35 \mathrm{c}$ \\
\hline Crop water productivity (CWP) $\left(\mathrm{kg} \mathrm{m}^{-3}\right)$ & $1.68 \mathrm{a}$ & $1.69 \mathrm{a}$ & $1.10 \mathrm{c}$ & $1.23 \mathrm{~b}$ \\
\hline
\end{tabular}

a] Field ET, yield, and CWP values followed by different letters are significantly different across the row at $\mathrm{p}=0.05$ using the Holm-Sidak method.

[b] DOY 142 to 296 for east lysimeters, and DOY 136 to 288 for west lysimeters.

Table 4. Irrigation, precipitation, evapotranspiration (ET), yield, and crop water productivity for corn in 2016. Yields are combine-harvested and adjusted to zero water content (dry). The NE and SE fields were irrigated with SDI, and the NW and SW fields were irrigated with MESA. The NE, SE, and SW fields were fully irrigated. The NW field was irrigated at $75 \%$ of the SW field beginning on DOY 161 (9 June). ${ }^{\text {[a] }}$

\begin{tabular}{|c|c|c|c|c|}
\hline \multirow[b]{2}{*}{ Corn in 2016} & \multicolumn{4}{|c|}{ Field and Lysimeter (and Irrigation Method) } \\
\hline & $\begin{array}{c}\mathrm{NE} \\
(\mathrm{SDI})\end{array}$ & $\begin{array}{c}\mathrm{SE} \\
(\mathrm{SDI})\end{array}$ & $\begin{array}{c}\text { NW } \\
(\mathrm{MESA} 75 \%)\end{array}$ & $\begin{array}{c}\text { SW } \\
(\text { MESA } 100 \%)\end{array}$ \\
\hline Preplant irrigation (mm) & 0 & 0 & 0 & 0 \\
\hline Irrigation from planting to $25 \mathrm{DAP}(\mathrm{mm})$ & 34 & 34 & 33 & 36 \\
\hline Irrigation after $25 \mathrm{DAP}(\mathrm{mm})$ & 464 & 476 & 358 & 580 \\
\hline Total irrigation $(\mathrm{mm})$ & 498 & 510 & 392 & 616 \\
\hline Preplant precipitation (60 days before) (mm) & 108 & 99 & 102 & 88 \\
\hline Precipitation from planting to 25 DAP (mm) & 41 & 38 & 43 & 38 \\
\hline Precipitation after 25 DAP $(\mathrm{mm})$ & 198 & 195 & 195 & 202 \\
\hline Total growing season precipitation (mm) & 238 & 233 & 239 & 241 \\
\hline ET from planting to 25 DAP (mm) & 51 & 50 & 68 & 62 \\
\hline ET from DOY 157 to $285(\mathrm{~mm})$ & 677 & 685 & 728 & 819 \\
\hline Total lysimeter ET $(\mathrm{mm})$ & 728 & 736 & 796 & 882 \\
\hline Total field ET (neutron probe basis) (mm) & $750 \mathrm{~b}$ & $718 \mathrm{c}$ & $717 \mathrm{c}$ & $860 \mathrm{a}$ \\
\hline Dry grain yield $\left(\mathrm{Mg} \mathrm{ha}^{-1}\right)$ & $11.92 \mathrm{~b}$ & $12.31 \mathrm{~b}$ & $9.76 \mathrm{c}$ & $13.04 \mathrm{a}$ \\
\hline Crop water productivity (CWP) $\left(\mathrm{kg} \mathrm{m}^{-3}\right)$ & $1.59 \mathrm{~b}$ & $1.71 \mathrm{a}$ & $1.36 \mathrm{c}$ & $1.52 \mathrm{~b}$ \\
\hline
\end{tabular}
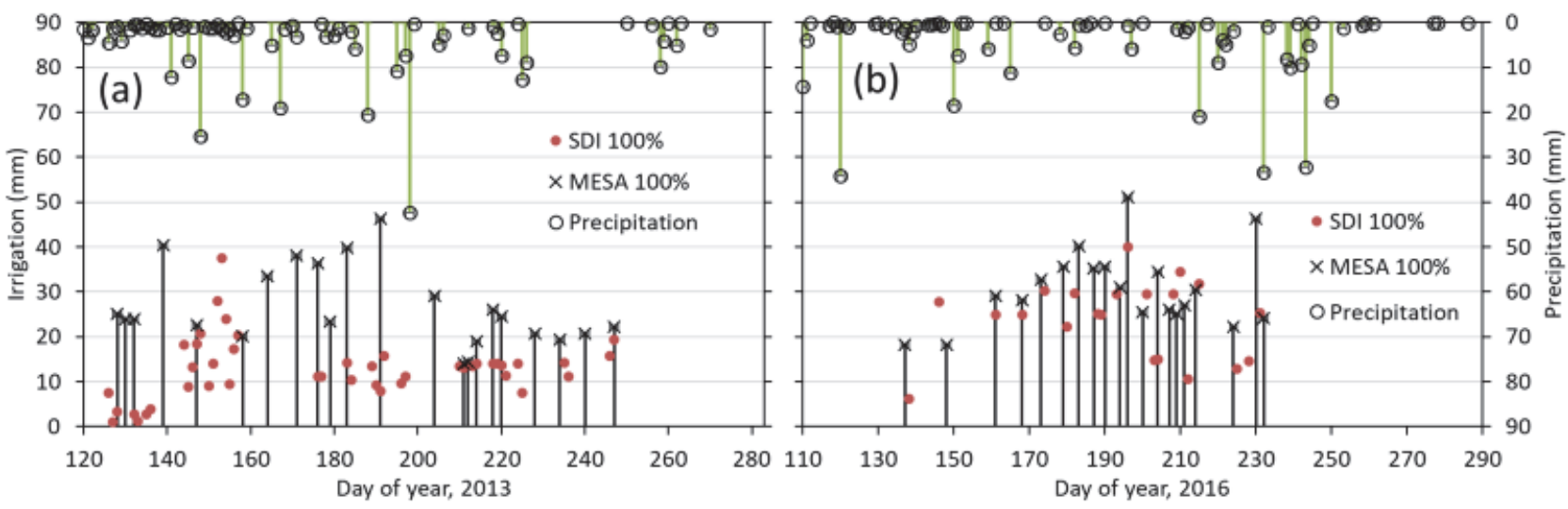

Figure 1. Precipitation and $100 \%$ irrigation events and amounts in east (NE and SE) and west (NW and SW) fields in (a) 2013 and (b) 2016. 

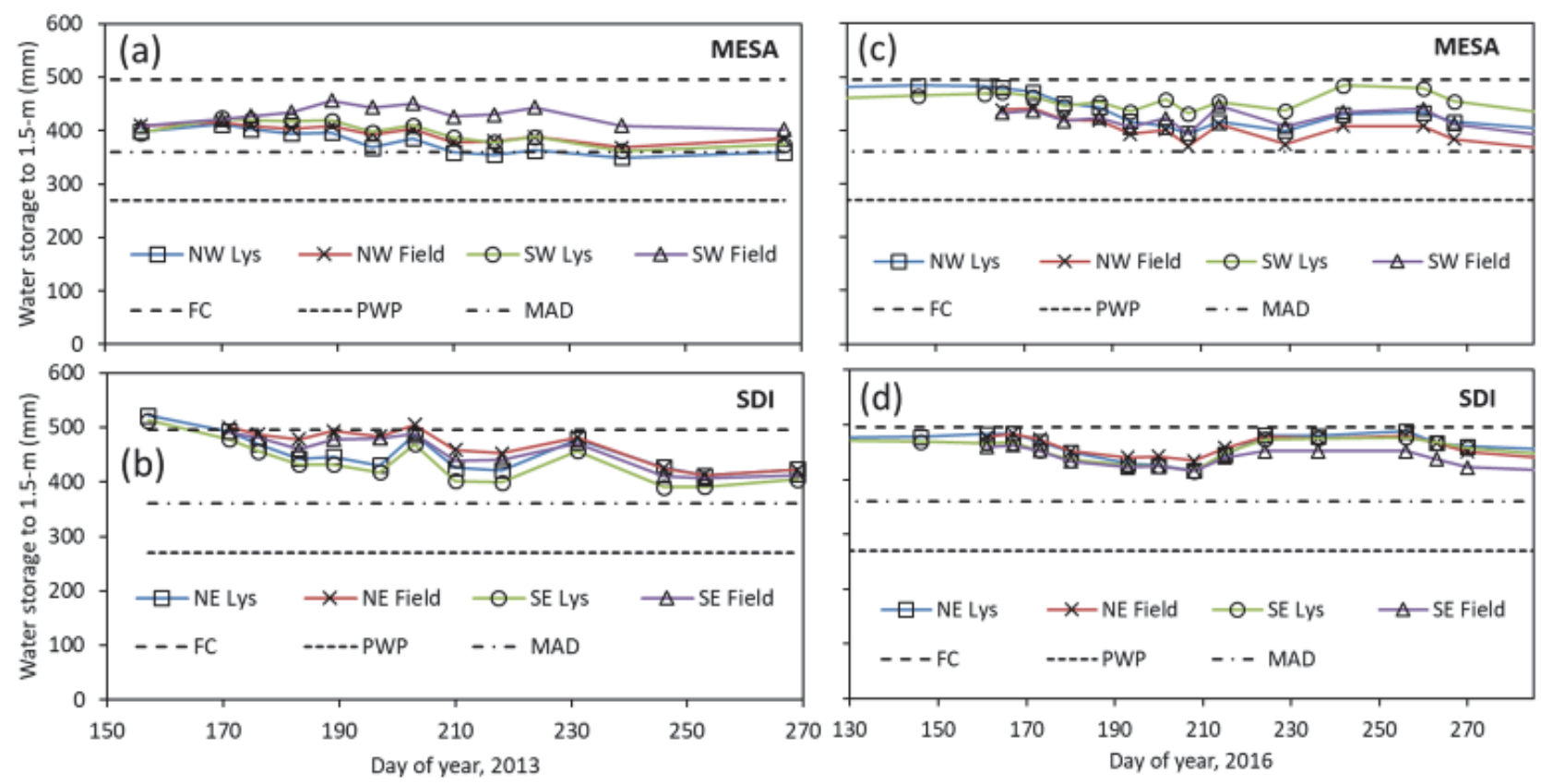

Figure 2. Water stored in the top $1.5 \mathrm{~m}$ of the soil profile for MESA irrigated fields and SDI fields in (a and b) 2013 and (c and d) 2016.

Crop coefficients were described in terms of days after planting (DAP) and growing degree days (GDD). GDD was calculated using equation 2 (NDAWN, 2020):

$$
\begin{aligned}
\mathrm{GDD} & =\frac{\left(T_{u}+T_{\min }\right)}{2}-T_{b}, & & T_{\max } \geq T_{u} \text { and } T_{\min } \geq T_{b} \\
& =T-T_{b}, & & T_{b} \leq T_{\max } \leq T_{u} \text { and } T_{\min } \geq T_{b} \\
& =\frac{\left(T_{\max }+T_{b}\right)}{2}-T_{b}, & & T_{b} \leq T_{\max } \leq T_{u} \text { and } T_{\min } \leq T_{b} \\
& =0, & & T_{\max } \leq T_{b} \text { and } T_{\min } \leq T_{b}
\end{aligned}
$$

where $T_{u}$ is the upper temperature threshold (taken as $30^{\circ} \mathrm{C}$ ), $T_{b}$ is the base temperature (taken as $10^{\circ} \mathrm{C}$ ), and $T$ is the mean of the daily maximum and minimum temperatures $\left(T_{\max }\right.$ and $T_{\min }$, respectively). Accumulative growing degree days (AGDD) were calculated starting from the day of planting.

Functions of $K_{c b}$ versus DAP and AGDD were developed using the line-segment model of FAO 56 in which the first part of the function, from planting to the initiation of rapid leaf area index (LAI) development, is described by a horizontal line at a value called $K_{c b \text { INI }}$; the second part of the function is a sloping line drawn from the value of $K_{c b_{-} I N I}$ at the time of initiation of rapid LAI development to the maximum value of $K_{c b}\left(K_{c b \_}\right.$MID $)$when this occurs at full LAI development; the third part of the function is a horizontal line at the value of $K_{c b_{-} \text {MID }}$, extending from the time of full LAI development to the time when $K_{c b}$ begins to decline with leaf senescence; and the fourth part of the function is a sloping line descending from the value of $K_{c b \_} M I D$ at the time when $K_{c b}$ begins to decline due to crop senescence.

\section{RESULTS}

Because corn is a "tall" crop, simple $K_{c}$ values based on the "tall" crop reference ET (ET $r$, also known as alfalfa reference ET) are discussed herein; however, because crop coefficients in FAO 56 are based on the "short" grass reference ET $\left(\mathrm{ET}_{o}\right)$, simple $K_{c}$ values based on $\mathrm{ET}_{o}$ are also discussed in comparison with $K_{c b}$ values from FAO 56 . Simple $K_{c}$ values based on $\mathrm{ET}_{r}$ ranged to greater than 1.0 during the MID period for the $100 \%$ MESA irrigation but remained mostly at or less than 0.9 for SDI (fig. 3). Simple $K_{c}$ for the $75 \%$ MESA irrigation was similar in magnitude to that for SDI during the MID period. Values of $K_{c}$ for the period from $16 \mathrm{~d}$ before planting to $20 \mathrm{~d}$ after planting were quite variable depending on precipitation and MESA irrigation events, as shown in figure 1 . The decline in $K_{c}$ that was evident in the middle of the MID period was more pronounced for SDI. This decline was associated with a period of rain beginning on DOY 195 followed by a period of cloudy weather that reduced transpiration. There was more variability in the data from the $75 \%$ MESA irrigation treatment in the period from $20 \mathrm{~d}$ after planting through MID and senescence. This was likely due to the crop running short of water and curtailing transpiration quickly after irrigations. The lack of water reserves in the $75 \%$ MESA treatment is also indicated by the quick decline in $K_{c}$ after MID and the clear responses to three precipitation events that occurred during senescence on days of year (DOY) 232, 243, and 250. After each precipitation event, the $K_{c}$ value in the $75 \%$ MESA treatment increased and then rapidly declined. During the same period, the $K_{c}$ values for SDI and the $100 \%$ MESA treatment remained larger and less variable over time.

Comparing $K_{c}$ from the $100 \%$ SDI treatments (averaged) to $K_{c}$ from the $100 \%$ MESA treatment illustrated the decrease in $K_{c}$ for SDI relative to MESA irrigation in 2013, where the overall $K_{c}$ for SDI was 0.81 of that for MESA (figs. $4 \mathrm{a}$ and $4 \mathrm{c}$ ). The ratio of $K_{C_{-} S D I}$ to $K_{C_{-} M E S A}$ varied according to crop development (fig. 4c). During the pre-irrigation period before planting, the simple $K_{c_{-} S D I}$ was 0.5 of that for MESA irrigation. For $12 \mathrm{~d}$ after planting the $K_{C S} S D I$ was 0.73 of that for MESA. Negative $\mathrm{r}^{2}$ values for these two regressions indicate that forcing the regression through the origin 

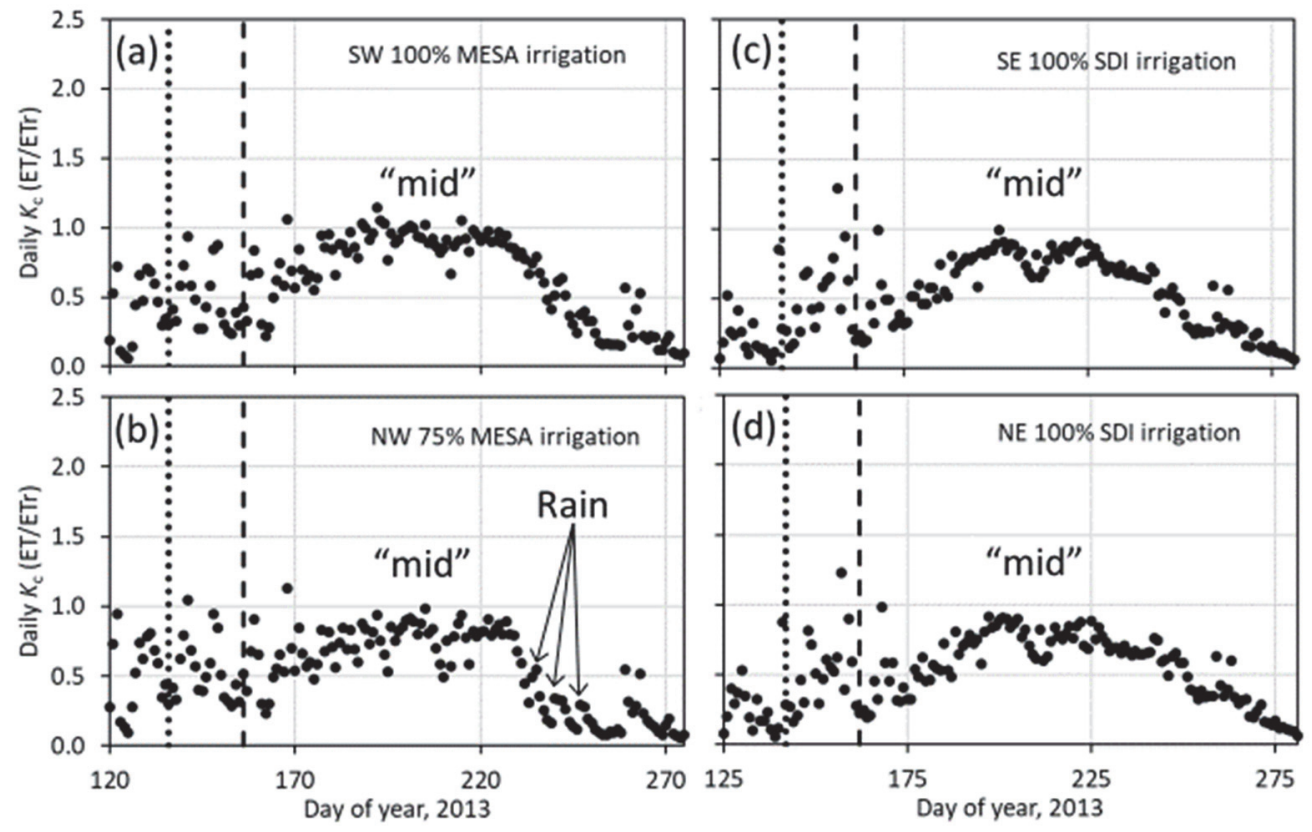

Figure 3. Simple $K_{c}$ values (ET/ET ${ }_{r}$ ) from approximately $16 \mathrm{~d}$ before planting to senescence in 2013 for (a) $100 \%$ MESA irrigation, (b) $75 \%$ MESA irrigation, and (c and d) $100 \%$ SDI. Vertical dotted lines indicate planting, and vertical dashed lines indicate $20 \mathrm{~d}$ after planting.

was not entirely appropriate (it was done for illustrative purposes) because the intercepts were not zero; and the slope of the relationship for the regression on days-before-planting data was actually negative. This likely occurred because the planting date was nearly a week different between the SDI and MESA fields, so the comparison was between data from one week in the $100 \%$ SDI fields and another week in the $100 \%$ MESA field.

During the grain filling stage after DOY 236, $K_{C_{-} S D I}$ was nearly always greater than $K_{C_{-} M E S A}$. This extra water use during grain filling was noted by Evett et al. (2019), who attributed larger yields with SDI in part to greater water use by SDI during this period. The larger water use was made possible by reduced evaporative loss and deeper soil wetting and possibly rooting with SDI. Howell et al. (2006) found $K_{c}$ for $\mathrm{ET}_{r}$ to be near 1.0 during MID, in agreement with $K_{c b}$ values for Kimberly, Idaho, reported by Wright (1982), and they found $K_{c}$ for $\mathrm{ET}_{o}$ during MID to be near the 1.17 value of $K_{c b}$ for Davis, California, reported by Jensen et al. (1990).

Allen et al. (1998) gave the days for corn growth stages as 30 for initial (INI), 40 for the development phase of rapid leaf area increase (DEV), 50 for the mid-season period of maximum $K_{c}$ (MID), and 50 for the late season (LATE) decline of $K_{c}$, for a total of $170 \mathrm{~d}$ before the END stage for April planting of grain corn in Idaho. For $K_{c}$ calculated using $\mathrm{ET}_{o}$, they gave: $K_{c b_{-} I N I}=0.15, K_{c b_{-} M I D}=1.15$, and $K_{c b_{-} E N D}=$ 0.15 for corn grown for grain and allowed to dry in the field (table 17 of Allen et al., 1998). Applying equation 70 of Allen et al. (1998), the $K_{c b \text { MID }}$ value was adjusted for the windy, dry environment of Bushland, Texas, in 2013 to a value of 1.243, which resulted in the "FAO Kcb" line in figure $4 \mathrm{~b}$. The adjusted $K_{c b \_M I D}$ appeared appropriate for MESA irrigated corn, at least for the first part of the mid-season, but was too large for SDI. In addition, the initial period appeared to be about $10 \mathrm{~d}$ too long. Decreasing the length of the initial period brought the $K_{c b}$ function in line with the minimal simple $K_{c}$ values from MESA irrigation for the development period and the first part of the mid-season period but appeared to be too small for the initial period ("FAO Kcb-2" line in fig. $4 \mathrm{~b}$ ). In addition, the mid-season period was too long for the hybrid grown and the conditions under which it was grown.

The $K_{c b}$ values calculated using equation 70 of Allen et al. (1998) were calculated assuming that the fraction of soil surface wetted by MESA irrigation was total, i.e., $f_{w}=1$. For SDI, the value of $f_{w}$ would be near zero, but changing the value to 0.01 for SDI did not change the calculated value of $K_{c b}$ MID. Allen et al. (1998) suggested that $K_{c}$ values could be reduced by 0.10 for surface applied drip irrigation beneath plastic mulch, which is in some ways similar to the case for SDI where the dry soil surface acts as the mulch, and they suggested that $K_{C_{-} I N I}$ could be as small as 0.10 under plastic mulch, which would be smaller than the $K_{c b I N I}$ that we observed in 2013 data in the initial period. Following this concept and the suggestions in example 45 ("Effects of surface mulch") of Allen et al. (1998), we reduced the $K_{c b \_M I D}$ and $K_{c b_{-} E N D}$ values by $10 \%$, resulting in $K_{c b_{-} M I D}=1.119$ and $K_{c b E N D}=0.135$. These values resulted in a $K_{c b}$ function ("FAO Kcb-3" line in fig. 4b) that was much closer to the minimal values of the $2013 K_{c}$ data for SDI during the crop development (DEV) period but much smaller than the simple $K_{c}$ values during the initial (INI) period. However, during the mid-season (MID) period, this $K_{c b}$ function was larger than most simple $K_{c}$ values for SDI and did not match our SDI $K_{c}$ or MESA $K_{c}$ values during the late MID or END periods (fig. $4 \mathrm{~b}$ ). The decline in $K_{c}$ values for both MESA and SDI during the mid-season is difficult to explain, given that soil water storage was greater than the maximum allowed depletion for both $100 \%$ MESA irrigation and SDI (fig. 2). The decline in $K_{c}$ in senescence beginning at about 100 DAP may be attributed to the drought-resistant hybrid grown, 

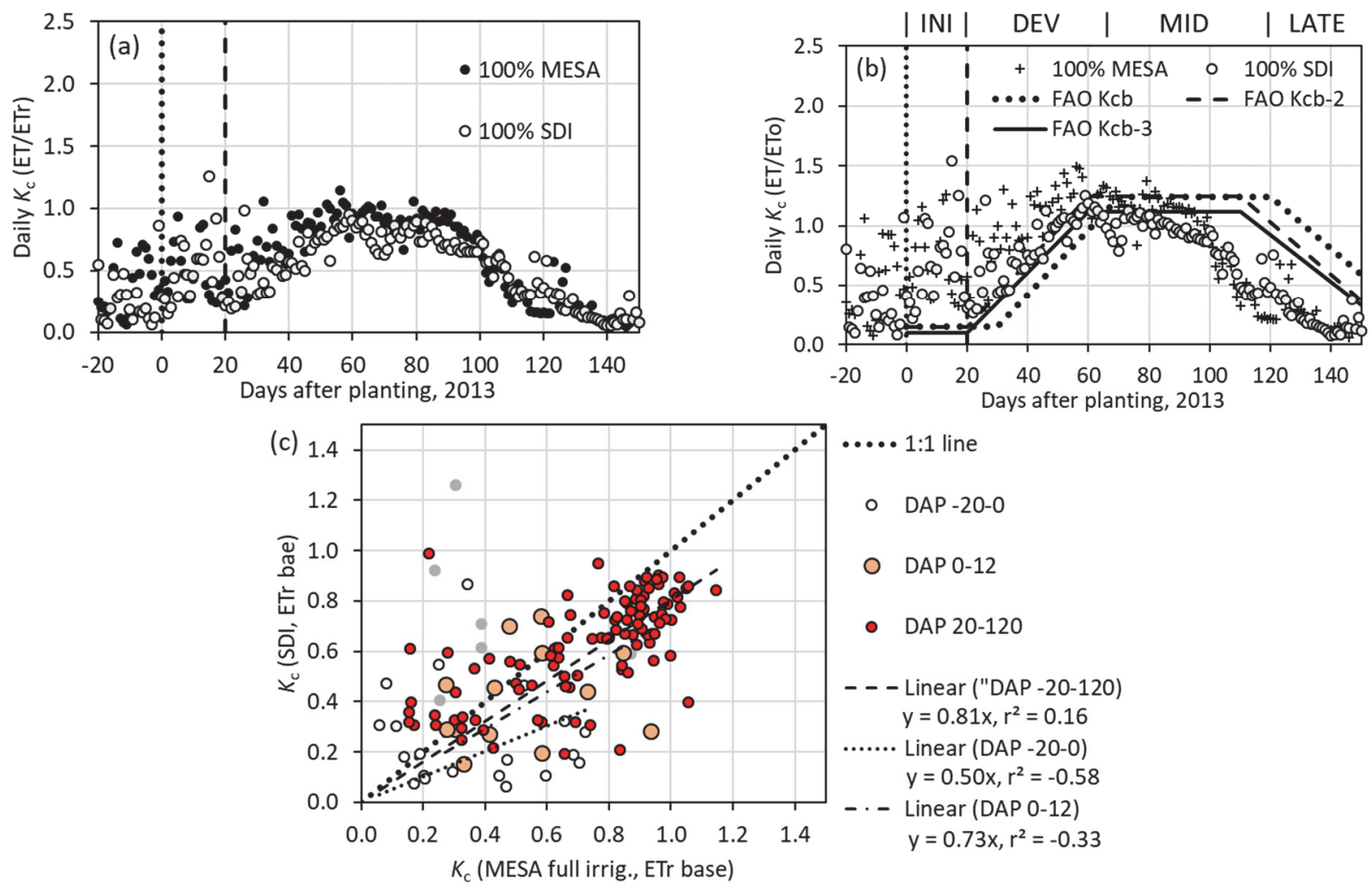

Figure 4. (a) Simple $K_{c}$ for SDI plotted with simple $K_{c}$ for MESA irrigation in 2013, both with $100 \%$ replenishment of soil water depletion on a weekly basis. Vertical dotted line indicates planting, and vertical dashed line indicates $20 \mathrm{~d}$ after planting.

(b) Simple $K_{c}$ based on ET ${ }_{o}$ for SDI and MESA irrigation in 2013 with climate-adjusted $K_{c b}$ lines from Allen et al. (1998): FAO Kcb (dotted line) is based on the original ( $30 \mathrm{~d}$ ) initial (INI) period with original lengths of the development (DEV), mid-season (MID), and late season (LATE) periods; FAO Kcb-2 (dashed line) is based on a shorter (20 d) initial period with the other values the same; and FAO Kcb-3 (solid line) is based on the $K_{c_{-} I N I}$ and $K_{c b_{-} M I D}$ values adjusted for drip irrigation under plastic mulch and with a $20 \mathrm{~d}$ initial period.

(c) Regression lines and equations, with intercept set to zero, plotted for data from different periods of the season. Gray symbols represent data not included in the DAP -20 to 0, DAP 0 to 12, and DAP 20 to 120 periods (DAP = days after planting).

which is known to finish grain filling earlier than previous varieties. Shortening the MID period by $10 \mathrm{~d}$ would be more realistic for this variety.

In 2016, the initial soil profile was much wetter than in 2013. With continued precipitation, the values of $K_{c}\left(\mathrm{ET}_{r}\right.$ basis) for the $75 \%$ MESA irrigation treatment were only slightly smaller than those for the $100 \%$ MESA treatment, about 0.05 smaller on average (figs. $5 \mathrm{a}$ and $5 \mathrm{~b}$ ). Values of $K_{c}$ for $100 \%$ SDI were about $15 \%$ smaller on average than those for $100 \%$ MESA irrigation (figs. 5c and 5d). Overall, there was less variability over time for the 2016 data compared with the 2013 data. Two wetting events prior to planting were followed by dry days during which $K_{c}$ decreased to basal $K_{c}$ values for both SDI and MESA irrigation. Multiple rainfalls during senescence kept the crop well-watered despite the discontinuation of irrigation so that $K_{c}$ did not decrease as rapidly in that period as it did in 2013.

Comparing $K_{c}$ from the $100 \%$ SDI treatments (averaged) with $K_{c}$ from the $100 \%$ MESA treatment illustrated the overall decrease in $K_{c}$ for SDI relative to MESA irrigation in 2016 (fig. 6a). Unlike in 2013, the $K_{c}$ values for SDI did not exceed those for MESA late in the season. The 2016 growing season also appeared to be longer than that for 2013. Values of $K_{c}$ for SDI were 0.87 of those for MESA considering the entire season (fig. 6c). For the period from planting to $20 \mathrm{~d}$ after planting, the $K_{c}$ for SDI was 0.83 of that for MESA irrigation. For the period from $20 \mathrm{~d}$ before planting, which included two rainfall events, the $K_{c}$ for SDI was nearly the same as that for MESA irrigation, with a positive offset of 0.04 . Applying equation 70 of Allen et al. (1998), the $K_{c b \_}$MID value was adjusted for the 2016 environment at Bushland, Texas, to a value of 1.220, which was compared with the $K_{c}$ based on $\mathrm{ET}_{o}$ in figure $6 \mathrm{~b}$ ("FAO Kcb" line). As in 2013, the 2016 adjusted $K_{c b}$ MID appeared appropriate for MESA irrigated corn but was clearly too large for SDI. The $K_{c b I N I}$ was clearly too large for both the MESA and SDI data. In addition, the initial period again appeared to be about $10 \mathrm{~d}$ too long. Similar to the 2013 data, decreasing the length of the initial period to $20 \mathrm{~d}$ brought the $K_{c b}$ function in line with the $K_{c}$ values from MESA irrigation for the development period and the first part of the mid-season period ("FAO Kcb-2" line in fig. 6b), but the duration of the mid-season period was too long for the hybrid grown and the conditions under which it was grown.

We again followed the suggestion of Allen et al. (1998) that $K_{c}$ values could be reduced by 0.10 for drip irrigation beneath plastic mulch and their suggestion that $K_{C_{I I N I}}$ could be as small as 0.10 under plastic mulch, which would more closely match the $K_{c b_{I N I}}$ that we observed in the 2016 data. Following the suggestions in example 45 ("Effects of surface 

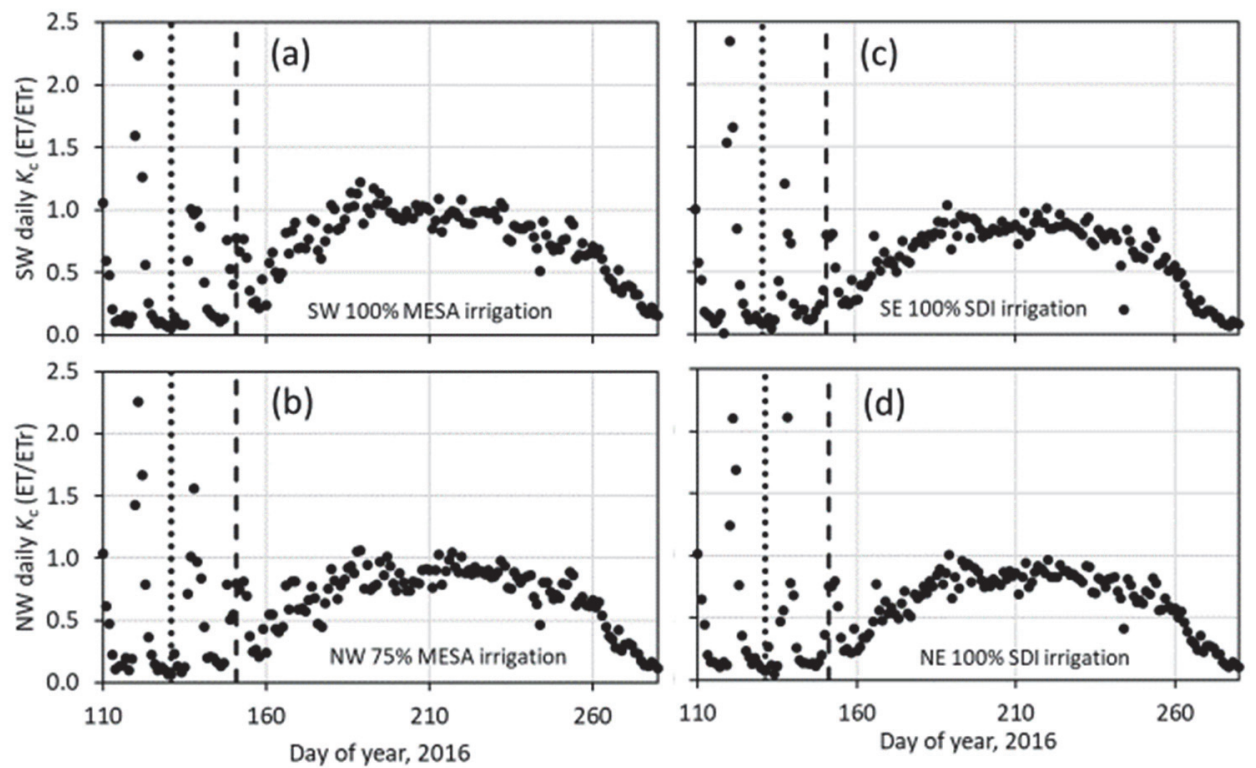

Figure 5. Simple $K_{c}$ values (ET/ET ${ }_{r}$ ) from approximately $20 \mathrm{~d}$ before planting to senescence in 2016 for (a) $100 \%$ MESA irrigation, (b) $75 \%$ MESA irrigation, and (c and d) $100 \%$ SDI. Vertical dotted lines indicate planting, and vertical dashed lines indicate $20 \mathrm{~d}$ after planting.
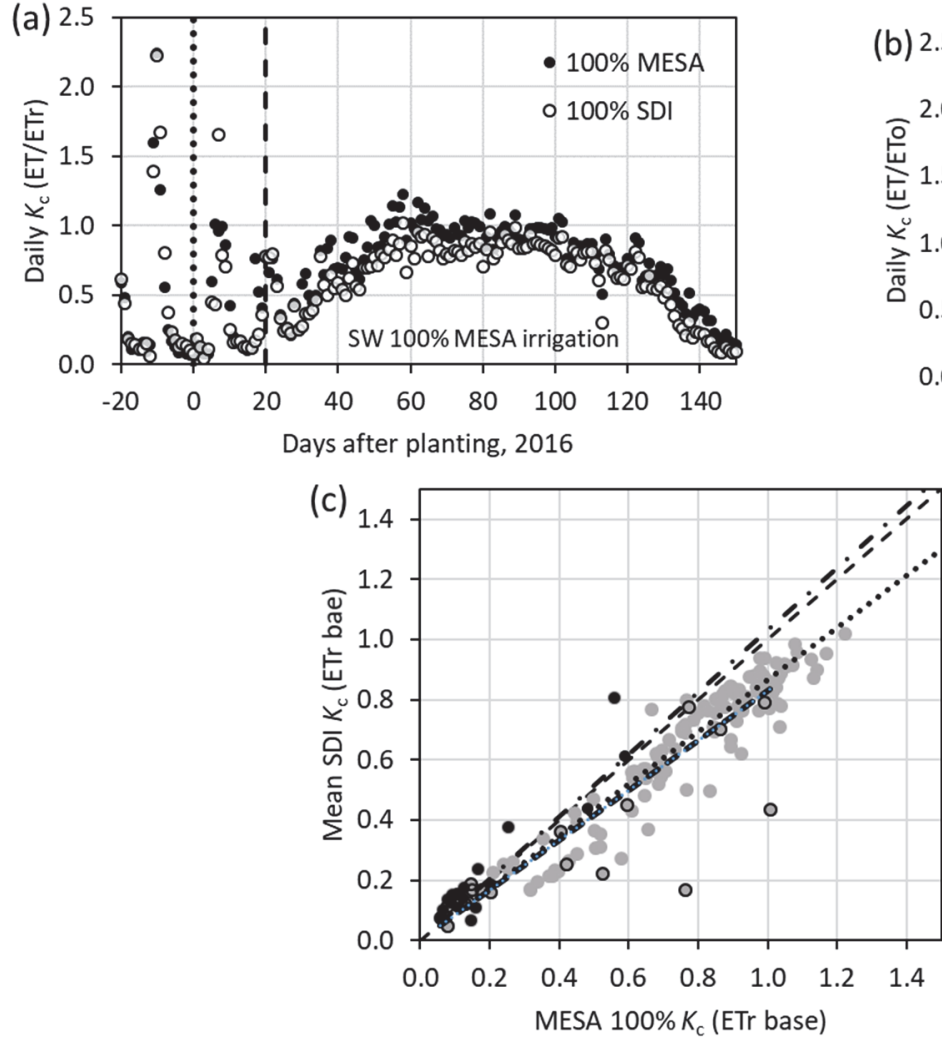
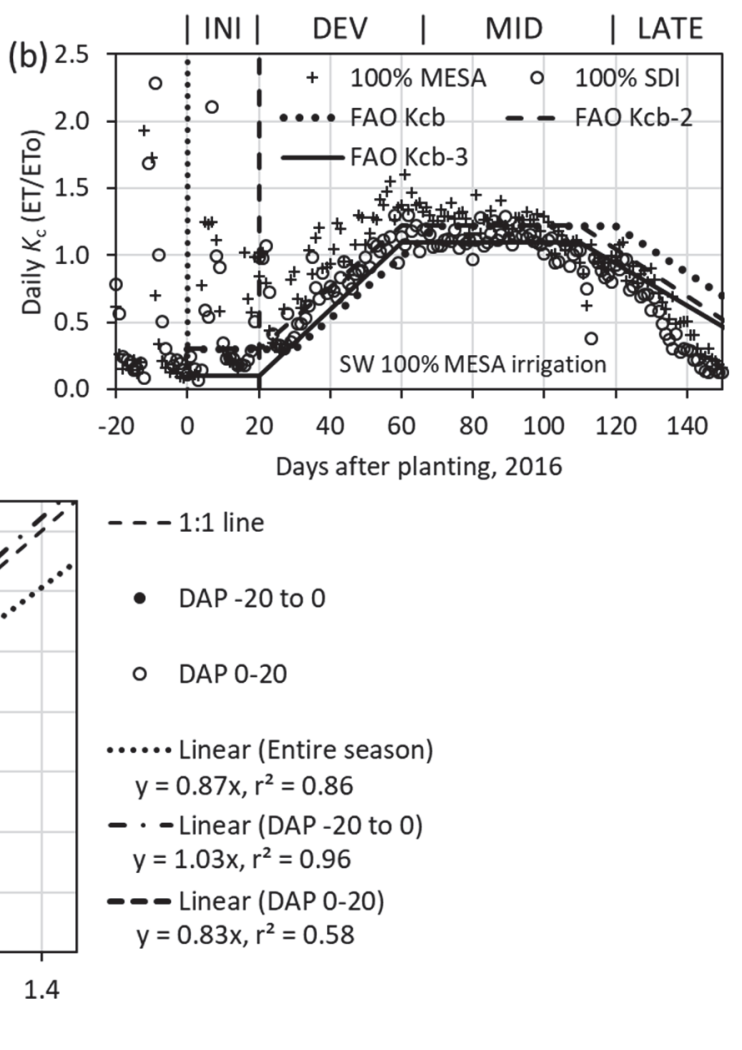

Figure 6. (a) Simple $K_{c}$ for SDI plotted with simple $K_{c}$ for MESA irrigation in 2016, both with $100 \%$ replenishment of soil water depletion on a weekly basis. Vertical dotted line indicates planting, and vertical dashed line indicates $20 \mathrm{~d}$ after planting.

(b) Simple $K_{c}$ based on ET F $_{o}$ for SDI and MESA irrigation in 2016 with climate-adjusted $K_{c b}$ plots from Allen et al. (1998): FAO Kcb (dotted line) is based on the original ( $30 \mathrm{~d}$ ) initial (INI) period with original lengths of the development (DEV), mid-season (MID), and late season (LATE) periods; FAO Kcb-2 (dashed line) is based on a shorter ( 20 d) initial period with the other values the same; and FAO Kcb-3 (solid line) is based on the $K_{c_{-} I N I}$ and $K_{c b_{-} M I D}$ values adjusted for drip irrigation under plastic mulch and with a $20 \mathrm{~d}$ initial period.

(c) Regression lines and equations plotted for data from the entire season and for the period from planting to $20 \mathrm{~d}$ after planting (DOY 131 to 151). Gray symbols represent data not included in the DAP -20 to 0 and DAP 0 to 20 periods (DAP = days after planting). 

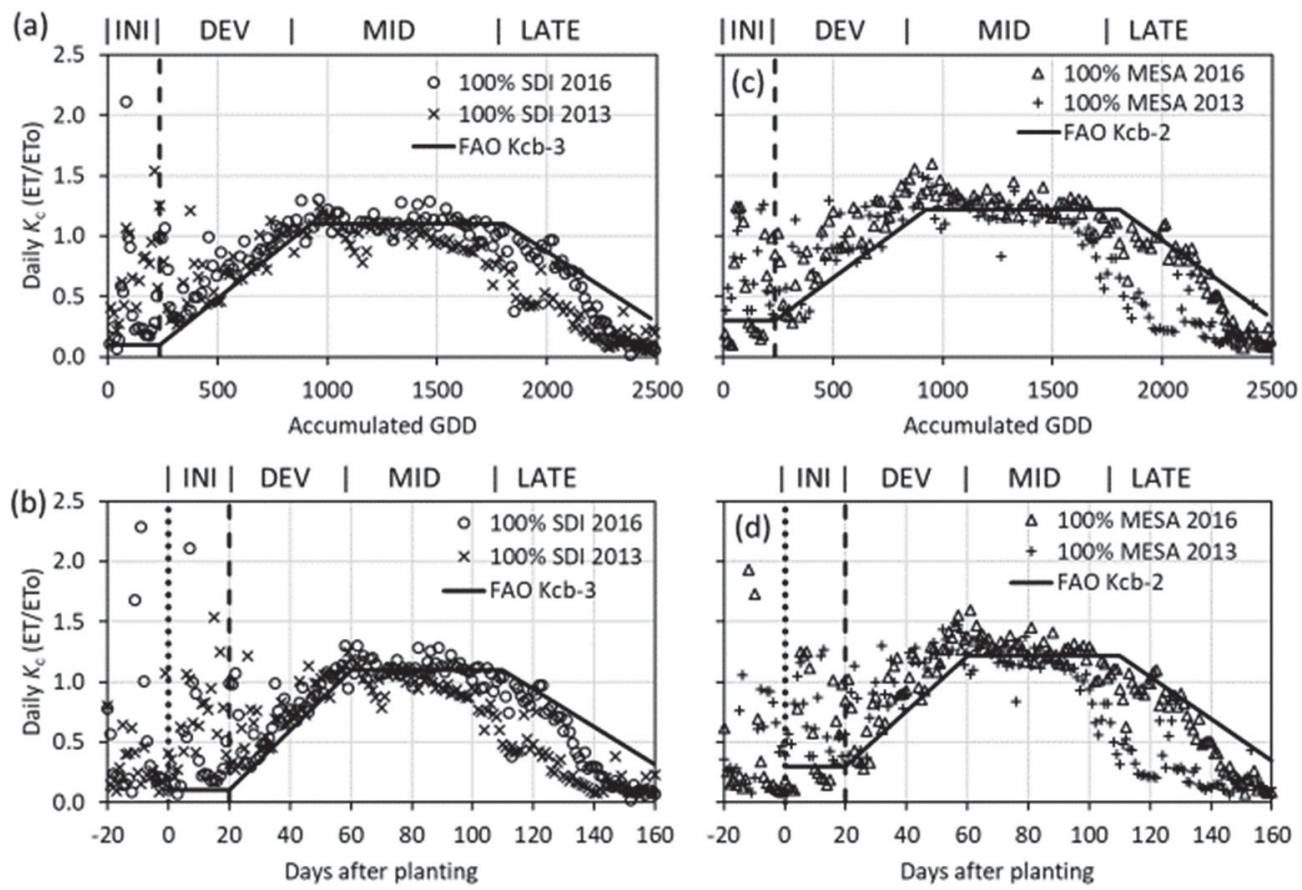

Figure 7. (a) Simple $K_{c}$ plotted versus accumulated growing degree days (AGDD) for SDI in 2013 and 2016 , (b) simple $K_{c}$ plotted versus days after planting for SDI in 2013 and 2016, (c) simple $K_{c}$ plotted versus accumulated growing degree days (AGDD) for 100\% MESA irrigation in 2013 and 2016, and (d) simple $K_{c}$ plotted versus days after planting for $100 \%$ MESA irrigation in 2013 and 2016 . Vertical dashed lines indicate 20 days after planting and 295 AGDD in 2013 or 234 AGDD in 2016 . Vertical dotted lines or zero on the $x$-axis indicate planting.

mulch") of Allen et al. (1998), we reduced the $K_{c b \text { MID }}$ and $K_{c b E N D}$ values by $10 \%$, resulting in $K_{c b M I D}=1.098$ and $K_{c b E N D}=0.315$. These values resulted in a $K_{c b}$ function that was much closer to the minimal values of the $2016 K_{c}$ data for SDI except for late in the mid-season and during the late season, when $K_{c}$ for SDI was still less than the calculated $K_{c b}$ ("FAO-Kcb-3" line in fig. 6b).

The relationships of simple $K_{c}$ versus DAP between 2013 (fig. 4b) and 2016 (fig. 6b) were quite different later in the season. Because the accumulation of heat units may be a better indicator of crop development than DAP, we plotted simple $K_{c}$ for SDI versus both accumulated growing degree days (AGDD) (fig. 7a) and versus DAP (fig. 7b) for the 2013 and 2016 corn crops. We did the same for the $100 \%$ MESA irrigated 2013 and 2016 corn crops (figs. 7c and 7d). Using AGDD did not appreciably change the differences in lateseason $K_{c}$ between the two years, indicating that the differences were not related to differences in heat unit accumulation over time. Indeed, we could say that the crop finished transpiring at about 2300 AGDD in both years and for both irrigation methods. Therefore, the late-season differences likely have another explanation. After $\sim$ DOY 230, the soil water content was larger in 2016 than in 2013. Several large rain events occurred during DOY 230 to 250 in 2016 (fig. 1), whereas 2013 was relatively dry later in the season. Thus, the late-season $K_{c}$ differences between 2013 and 2016 might be explained by considerably more late-season soil water evaporation in 2016 .

\section{CONCLUSION}

For both an $\mathrm{ET}_{o}$ basis and an $\mathrm{ET}_{r}$ basis, values of $K_{c}$ for SDI $\left(K_{c S D I}\right)$ remained consistently less than those for MESA irrigation $\left(K_{C_{-} M E S A}\right)$ even after maximum leaf area index was reached, indicating that considerable evaporative loss from the soil and plant surfaces occurred with MESA irrigation even after full canopy cover. Overall, the value of $K_{c_{-} S D I}$ ranged from 0.83 to 0.89 of $K_{c_{-} M E S A}$ for the two years, but $K_{c_{-} S D I}$ was only 0.52 to 0.61 of that for MESA irrigation during pre-irrigation and before emergence in 2013. In 2016, $K_{c S D I}$ was similar to $K_{c}$ MESA for $20 \mathrm{~d}$ before planting and was 0.83 of that for MESA in the $20 \mathrm{~d}$ after planting. Because $K_{c_{-} S D I}$ was consistently less than $K_{c_{-} M E S A}$ after 20 DAP, it is appropriate to discount by approximately $10 \%$ the irrigation depths calculated using $K_{c}$ values developed using sprinkler irrigation. It is similarly appropriate to apply the recommendations of Allen et al. (1998) for surface drip irrigation under full-cover plastic mulch to our case of SDI with drip lines buried at $\sim 0.32 \mathrm{~m}$. Following those recommendations decreased $K_{c b \_M I D}$ by $10 \%$ during the mid-season, consistent with our finding, and decreased $K_{c b_{-} I N I}$ to 0.10 and $K_{c b} E N D$ by $10 \%$ from the values given in table 17 of Allen et al. (1998) for grain corn grown to field-dry condition. For SDI, following these changes and decreasing the length of the initial period from $30 \mathrm{~d}$ to $20 \mathrm{~d}$ provided reasonably good fits of $K_{c b}$ to our data from planting to at least halfway through the mid-season period in both 2013 and 2016 and fairly good fit to our 2016 data all the way to halfway through the late period of senescence. For MESA irrigation at $100 \%$, following the table 17 values for grain corn with a decrease of the 
initial period from $30 \mathrm{~d}$ to $20 \mathrm{~d}$ provided reasonable fits to our data during the development period and part way through the mid-season for both 2013 and 2016, and good fit for the initial period in 2013 but not in 2016, where our $K_{c}$ values were much less. Later in the mid-season and late seasons of both years, our $K_{c}$ values were less or much less than those calculated using the recommendations of Allen et al. (1998). We leave to another study the question of whether the dual-coefficient approach of Allen et al. (1998) involving evaporation from the soil surface can adequately describe our corn crop ET and further resolve the differences between SDI and sprinkler application.

\section{ACKNOWLEDGEMENTS}

We acknowledge congressionally funded support from the USDA-ARS Ogallala Aquifer Program, a consortium between the USDA Agricultural Research Service, Kansas State University, Texas A\&M AgriLife Research, Texas A\&M AgriLife Extension Service, Texas Tech University, and West Texas A\&M University. We are grateful for the dedicated support of Karen S. Copeland, Soil Scientist, Brice B. Ruthardt, Biological Scientist, and Gwen G. Coyle, Agricultural Science Research Technician (Plants).

\section{REFERENCES}

Allen, R. G. (2012). REF-ET, Reference evapotranspiration calculator, Ver. 3.1.07. Kimberly, ID: University of Idaho Research and Extension Center.

Allen, R. G., Pereira, L. S., Raes, D., \& Smith, M. (1998). Crop evapotranspiration: Guidelines for computing crop water requirements. Irrigation and Drainage Paper No. 56. Rome, Italy: United Nations FAO.

ASCE. (2005). The ASCE standardized reference evapotranspiration equation. Reston, VA: ASCE. https://doi.org/10.1061/9780784408056

Colaizzi, P. D., Evett, S. R., \& Howell, T. A. (2006a). Cotton production with SDI, LEPA, and spray irrigation in a thermally limited environment. Intl. Water Irrig., 26(1), 10-12, 14.

Colaizzi, P. D., Evett, S. R., \& Howell, T. A. (2006b). Near-surface soil water and temperature for SDI, LEPA, and spray irrigation. Proc. 27th Annual Intl. Irrigation Show Tech. Conf. Falls Church, VA: Irrigation Association.

Colaizzi, P. D., Evett, S. R., Howell, T. A., \& Baumhardt, R. L. (2009). Comparison of grain sorghum, soybean, and cotton production under spray, LEPA, and SDI. Proc. 21st Annual Central Plains Irrig. Conf. (pp. 122-139). Colby, KS: Central Plains Irrigation Association.

Colaizzi, P. D., Schneider, A. D., Evett, S. R., \& Howell, T. A. (2004). Comparison of SDI, LEPA, and spray irrigation performance for grain sorghum. Trans. ASAE, 47(5), 1477-1492. https://doi.org/10.13031/2013.17628

Evett, S. R., Heng, L. K., Moutonnet, P., \& Nguyen, M. L. (Eds.) (2008). Field estimation of soil water content: A practical guide to methods, instrumentation, and sensor technology. Vienna, Austria: International Atomic Energy Agency.

Evett, S. R., Howell Sr., T. A., Schneider, A. D., Copeland, K. S., Dusek, D. A., Brauer, D. K., ... Gowda, P. H. (2016). The Bushland weighing lysimeters: A quarter century of crop ET investigations to advance sustainable irrigation. Trans. ASABE, 59(1), 163-179. https://doi.org/10.13031/trans.59.11159
Evett, S. R., Kustas, W. P., Gowda, P. H., Anderson, M. C., Prueger, J. H., \& Howell, T. A. (2012). Overview of the Bushland evapotranspiration and agricultural remote sensing experiment 2008 (BEAREX08): A field experiment evaluating methods for quantifying ET at multiple scales. $A d v$. Water Resour., 50, 4-19. https://doi.org/10.1016/j.advwatres.2012.03.010

Evett, S. R., Marek, G. W., Colaizzi, P. D., Brauer, D. K., \& O'Shaughnessy, S. A. (2019). Corn and sorghum ET, E, yield, and CWP as affected by irrigation application method: SDI versus mid-elevation spray irrigation. Trans. ASABE, 62(5), 1377-1393. https://doi.org/10.13031/trans.13314

Evett, S. R., Marek, G. W., Colaizzi, P. D., Ruthardt, B. B., \& Copeland, K. S. (2018a). A subsurface drip irrigation system for weighing lysimetry. Appl. Eng. Agric., 34(1), 213-221. https://doi.org/10.13031/aea.12597

Evett, S. R., Marek, G. W., Copeland, K. S., \& Colaizzi, P. D. (2018b). Quality management for research weather data: USDAARS, Bushland, TX. Agrosyst. Geosci. Environ., 1(1). https://doi.org/10.2134/age2018.09.0036

Howell, T. A., Evett, S. R., Tolk, J. A., \& Schneider, A. D. (2004). Evapotranspiration of full-, deficit-irrigated, and dryland cotton on the northern Texas High Plains. J. Irrig. Drain. Eng., 130(4), 277-285. https://doi.org/10.1061/(ASCE)07339437(2004)130:4(277)

Howell, T. A., Evett, S. R., Tolk, J. A., Copeland, K. S., \& Marek, T. H. (2015). Evapotranspiration, water productivity, and crop coefficients for irrigated sunflower in the U.S. Southern High Plains. Agric. Water Mgmt., 162, 33-46.

https://doi.org/10.1016/j.agwat.2015.08.008

Howell, T. A., Evett, S. R., Tolk, J. A., Copeland, K. S., Dusek, D. A., \& Colaizzi, P. D. (2006). Crop coefficients developed at Bushland, Texas, for corn, wheat, sorghum, soybean, cotton, and alfalfa. Proc. World Environmental and Water Resource Congress 2006: Examining the Confluence of Environmental and Water Concerns. Reston, VA: ASCE. https://doi.org/10.1061/40856(200)260

HPWD. (2016). Subsurface drip irrigation inventory. Lubbock, TX: High Plains Water District. Retrieved from http://www.hpwd.org/other

Jensen, M. E., Burman, R. D., \& Allen, R. G. (Eds.). (1990). Evaporation and irrigation water requirements. ASCE Manual of Practice No. 70. Reston, VA: ASCE.

Marek, T. H., Schneider, A. D., Howell, T. A., \& Ebeling, L. L. (1988). Design and construction of large weighing monolithic lysimeters. Trans. ASAE, 31(2), 477-484. https://doi.org/10.13031/2013.30734

Marek, G. W., Evett, S. R., Gowda, P. H., Howell, T. A., Copeland, K. S., \& Baumhardt, R. L. (2014). Post-processing techniques for reducing errors in weighing lysimeter evapotranspiration (ET) datasets. Trans. ASABE, 57(2), 499-515. https://dx.doi.org/10.13031/trans.57.10433

NDAWN. (2020). Corn growing degree days (GDD). Fargo, ND: North Dakota Agricultural Weather Network. Retrieved from https://ndawn.ndsu.nodak.edu/help-corn-growing-degreedays.html

Tolk, J. A., \& Howell, T. A. (2001). Measured and simulated evapotranspiration of grain sorghum grown with full and limited irrigation in three High Plains soils. Trans. ASAE, 44(6), 15531558. https://doi.org/10.13031/2013.7040

USDA-NASS. (2019). 2018 irrigation and water management survey, Vol. 3, Special studies, Part 1 (AC-17-SS-1). Washington, DC: USDA National Agricultural Statistics Service.

Wright, R. L. (1982). New evapotranspiration crop coefficients. $J$. Irrig. Drain. Div. ASCE, 108(R2), 57-74. 